\title{
Neutral or Biased? The Framing of the Kyrgyzstan and Egypt Uprisings by Ria Novosti
}

\author{
Tatiana Varacheva \\ Department of Political Science \\ Goethe University Frankfurt \\ Sergiu Gherghina \\ Department of Politics \\ University of Glasgow
}

This is an Author's Original Manuscript of an article published in

\author{
Europe-Asia Studies
}

\begin{abstract}
:
This article analyses the media of the uprisings in Kyrgyzstan (February-April 2005) and Egypt (JanuaryFebruary 2011) by the Russian news agency Ria Novosti. It aims to identify the features of framing by focusing on two dimensions: the promotion of a particular problem and its causal interpretation. Our analysis uses 184 articles published online by the news agency during the two events and differentiates between three types of articles (news stories, opinion articles and expert interviews). Our results indicate that although in general the agency was quite neutral, several framing nuances could bias public perception towards protesters or incumbents.
\end{abstract}

Keywords: media framing, uprisings, news agency, post-Soviet, Arab Spring.

\section{Introduction}

Popular uprisings, protest movements, upheavals or revolutions are specific events in a country's history and receive special attention from scholars and journalists. The waves of revolutions across different countries are particularly relevant to identify patterns, understand the mechanisms that make them spread, and provide explanations. Two recent waves are the Colour Revolutions in the post--Soviet countries in the early and mid. .2000s and the Arab Spring that started at the end of 2010 and was marked by mass protests and revolutions that spread with the remarkable speed and magnitude. Both waves were important events that led to the overthrown of several political regimes, had important domestic political effects, brought consequences for bilateral and multilateral relations, and had implications at regional and international levels (Bunce \& Wolchik 2006a; 2006b; Diamond 2011; Lynch 2014). Earlier studies tried to draw parallels between both waves by looking at a number 
of shared characteristics by embedding them into broader theoretical frameworks (Koesel \& Bunce 2013; Hess 2016).

In learning about these events and understanding them, many people use media as the main source of information. In the messages conveyed much depends on the framing, i.e. the focus on certain issues that can shape the public opinion (Entman 1993; Nelson et al. 1997; Scheufele 1999; Reese 2001). With respect to protest events earlier studies have shown how different types of media frame them (Peng 2008; Di Cicco 2010; Hamdy \& Gomaa 2012; Xu 2013; Gottlieb 2015) but many of them analysed single events. However, little has been done regarding media framing of popular mobilization events in a comparative perspective. To address this empirical void, this paper analyses the coverage of the movements in Kyrgyzstan (February-April 2005) and Egypt (January-February 2011) and identifies the ways in which the events were framed by the Russian Ria Novosti, one of the biggest online news agencies in the world. This study aims to answer the following research question: How does RIA Novosti frame the uprisings in Kyrgyzstan and Egypt? Our quest uses articles published online by the news agency and focuses on two dimensions: 1) the promotion of a particular problem and its evaluation and 2) the causal interpretation. The first dimension investigates whether the depiction of events is favourable, neutral or negative and which actor undertakes them: protesters, representatives of opposition or anti. -incumbent forces, incumbents (and authorities), and pro-incumbent demonstrators. The second dimension questions the causality of events and distinguishes between internal causal attributions with emphasis on domestic problems and socio-political grievances and external causality that stresses the foreign influence, "domino effect" or previous revolutions in the revolutionary wave.

The Russian media is selected for the frame analysis due to the particular links of Russia with both revolutionary waves: the Color Revolution occurred in the post-Soviet countries, close to Russia and under its sphere of influence, while the Arab Spring took place in a region considered as a bastion of authoritarianism with which Russia maintained good connections (and also shares features). The remainder of this paper proceeds as follows. The next section reviews the literature about media framing of protest movements, uprisings or revolutions and introduces the analytical framework used in the paper. The third section presents the research design with an emphasis on the case selection, data sources, sampling strategy, and provides an overview of the frame analysis as a method. Next we present the results of the empirical analysis: the news stories, opinion articles and expert interviews published by RIA Novosti during the uprisings. The conclusions summarize the results of the empirical analysis, outline their implications for the broader study of media framing and suggest avenues for further research. 


\section{Framing of protests and revolutions}

In spite of an extensive literature using frames and framing, there is little consensus about them. Goffman (1974, p.21) sees frames as "frameworks of schemata of interpretation" that allow individuals "to locate, perceive, identify, and label" occurrences in their daily life and in the society. Gitlin (1980, pp.6-7) argues that "frames are principles of selection, emphasis, and presentation composed of little tacit theories about what exists, what happens, and what matters"; specifically, media frames are "persistent patterns of cognition, interpretation, and presentation, of selection, emphasis, and exclusion, by which symbol-handlers routinely organize discourse, whether verbal or visual". Another central definition of frames considers them "a central organizing idea or story line that provides meaning to an unfolding strip of events" (Gamson \& Modigliani 1987, p.143). Frames define problems, provide a diagnosis of causes, moral judgment, and suggest remedies suggestion. Frames are to be identified in a text by "the presence or absence of certain keywords, stock phrases, stereotyped images, sources of information, and sentences that provide thematically reinforcing clusters of facts or judgments" (Entman 1993, p.52). News frames have effects on peoples' opinions by emphasizing particular elements and stressing some central aspects out of the controversies of the issue (Nelson et al. 1997, p.568). Reese (2001, p.11) introduces his working definition of frames as "organizing principles that are socially shared and persistent over time, that work symbolically to meaningfully structure the social world". Emphasizing the idea that frames are perceived as abstract principles or organizing information and pointing at their symbolic manifestation, he also notes that frames vary in the extent they organize information, persist, are shared and structured.

The frame analysis is frequently used as a method to examine the presentation and the interpretation of the news (Khineyko 2005). In this sense, framing plays an important role and can be defined as "to frame is to select some aspects of a perceived reality and make them more salient in a communicating text, in such a way as to promote a particular problem definition, causal interpretation, moral evaluation, and/or treatment recommendation" (Entman 1993, p.52). According to another definition, "framing is the process by which a communication source, such as a news organization, defines and constructs a political issue or public controversy" (Nelson et al. 1997, p.567). Scheufele (1999) argues that the definition and conceptualization of framing should be embedded into the setting of social constructivism and provides a classification of frames that distinguishes between media and audience frames, and between dependent and independent frames.

To a great extent, the citizens' perception about protests and revolutionary events is influenced by their depiction in the media. Since protests can transform into uprisings, it is relevant to review also the literature on 
protest framing. On the one hand, government elite and obedient media traditionally take a hostile approach toward the threat posed by protesters and tend to diminish the contributions and effectiveness of protests. Watchdog or independent media objectively explores the stances of protesters accounting for all available facts (Gitlin 1977; 1980; McLeod \& Detenber 1999; Boyle et al. 2005). Attempts to marginalize and delegitimize the protest groups by the media are frequently explained with the "protest paradigm", according to which media oppose actions that threaten status quo and challenge current conditions, norms or policies (Shoemaker 1984; Boyle et al. 2005; Di Cicco 2010; Lee 2014). The "protest paradigm" approach targets demonstration strategies, theatrical aspects of the protests and appearances of protesters, stresses disunity among protesters, portrays protests as radical, emphasizes dramatic events and violence of the protests, marginalizes the protesters' goals, and privileges the sources and the perspectives of authorities setting public opinion against the protesters (Di Cicco 2010, p.136; Lee 2014, pp.2726-2728). Protesters are frequently presented as illegitimate political actors who lack a specific status (Shoemaker 1984).

Gitlin's (1980) analysis of the news coverage of the anti-war movement on the example of CBS News and the New York Times shows how the media first ignored the movement and then applied selective amplification emphasizing certain themes and scanting the others. In particular, the media tried to marginalize protesters, stress violence in demonstrations, disparage the movement's effectiveness, emphasize their internal dissentions, and rely on statements made by government officials and other authorities with the subsequent development of adversaries. However, the growing sympathy for the movement shifted the way it was framed in the news. Di Cicco's (2010) analysis of the coverage of social protests occurred in the United States between 1967 and 2007 in the U.S. mainstream newspapers shows that the protests were framed as ineffective, unpatriotic and bothersome.

On the other hand, from the perspective of protesters, their activity may be presented with the help of injustice frames, identification of culpable agents, bounding or adversarial frames that attempt to delineate the boundaries between protagonists and antagonists of a movement. Benford and Snow (2000) developed a framing model that provides an interpretation of issues with the intention to gain more supporters to the protest movements. The model consists of three core framing tasks: 1) diagnosis framing that focuses on blame and responsibility and identifies a problem; 2) prognosis framing that presents a solution to a problem and 3) motivational framing that attempts to give people a reason to join communicating rationale and motives for engagement. All factors, including cultural stock of the target audience, political and social context, should be taken into account in order to compete with the frames promoted by the state, countermovement and the media 
(Noakes \& Johnston 2005). This expectation on different framings of the same events by different parties was supported by several studies. In her analysis, Lundgren-Jörum (2012) reveals the differences in the interpretations of the developments of the Syrian revolution in 2011 provided by the government and the opposition. These differences lie in contrasting definitions given to the events, stances on the causes, the solutions to finish the crisis, the visions of the future, and claims regarding the forces behind the violence. So far, we defined the key concepts used in this paper and identified the main types of frames; let us now turn to the ways in which protests were framed in the media.

\section{Color Revolutions and Arab Spring}

The frame analysis has been widely used by a number of scholars to examine the media coverage of different types of protests and revolutions belonging to the two waves: Colour Revolutions in Eastern Europe and the Arab Spring. Previous research identified a number of frames that commonly occur in the media. Zhang and Fahmy (2009) compared the coverage of the Colour Revolutions in Ukraine, Belarus and Uzbekistan by The New York Times and The Moscow Times applying three frames: the sourcing frame, the causality frame and the moral judgment frame. According to the findings, in comparison with The New York Times, the Russian-based The Moscow Times used more Russian government and pro-incumbent sources, more unfavourable symbolic terms with regard to the protesters and stressed more on external attributions what indicates the concern over Russian interests.

Khineyko (2005) analysed the coverage of the Ukrainian presidential election in 2004 by six Russian daily newspapers and identified two main frames. The first one, the "political game", is based on the assumption of the similarity of the Russian and the Ukrainian political systems. It promotes the idea that the scenario with the appointment of the then Russian Prime Minister Vladimir Putin as Yeltsin's "heir" and the subsequent victory of the appointee should repeat in Ukraine. The second frame was the "Western melding" based on the idea that the adversarial Western countries are involved in the election campaign backing its candidate, Viktor Yushchenko. This pro-Western image became dominant in the portrayal of Yushchenko in the Russian print media, while Yanukovich was accepted as a candidate suitable for Russia only by one newspaper, the Rossiiskaia gazeta (Russian Gazette) published by the Russian government. The others shifted towards a more positive portrayal of Yanukovich only after he expressed his support to the official status of the Russian language and intention to integrate with Russia.

The Ukrainian Orange Revolution was the focus of the comparative frame analysis of The New York 
Times and Izvestia (News) newspapers conducted by Hubenko (2012). The New York Times emphasized the democratic nature of the protests and depicted the electoral fraud as a primary problem of the conflict in Ukraine and depicted the protests as a struggle of citizens for the democratic and transparent elections, downplaying a range of complex problems the country faced. On the contrary, Izvestia focused on the historical differences and split between "pro-Western" (or "anti--Russian") Western part of Ukraine and "pro--Russian" Eastern Ukraine and saw the Orange Revolution as a result of an internal conflict and split between the West and the East. Regarding the causes of the crisis, The New York Times saw the cause of the conflict in the corrupt Ukrainian government responsible for the falsifications and the influence of the Russian government. For the Russian Izvestia, the conflict was caused by the opposition candidate Viktor Yuschenko, and his supporters both in Ukraine and in the Western countries. The opposition sides were also presented differently: The New York Times' portrayal of Yushenko and his supporters was supposed to evoke sympathy of the readers, while Izvestia blamed them for radicalism, extreme nationalism, aggressiveness or conflict-orientation and covered his opponent Yanukovych in favourable terms, emphasizing his closeness to Russia. The New York Times aligned with the Western position in the conflict, called to recounting the votes and to rerunning the second round. The newspaper showed Western countries as the saviours of the Ukrainian democracy and the Russians as trying to interfere with Ukraine's affairs. Izvestia insisted on the legitimacy of Yanukovych's presidency and showed Western mediation as an intervention and an attempt to weaken the Russian influence in the post--Soviet sphere.

Hamdy and Gomaa (2012) compared the framing of the 2011 Egypt's uprising in the state's semiofficial newspapers, independent newspapers and social media posts. The researchers focused on four dimensions that intended to uncover the following aspects: how the protests were framed in general, how the nature of the protests was defined, which factors were portrayed as causes for the protests, and what solutions for ending the crisis were proposed. They found that the semi-official newspapers depended mostly on the conflict frame pointing at the harmfulness of the events, the independent newspapers attempted to frame the crisis in terms of its negative economic consequences. Unlike the traditional newspapers, the social media posts concentrated on the human interest frame that emphasized the sufferings of the ordinary Egyptians, ignoring conflict and economic consequences frames. Interestingly, responsibility frame in the semi-official media blamed the protesters for starting violence, whereas in the independent newspapers responsibility fell on the government, the police, the media, or a combination of all three. The responsibility frame in the social media focused on accusing the police for the use of violence and the killing of civilians. Their analysis also identified contrasting differences in the definition of the protests: independent newspapers and social media mostly 
recognized the happenings as a revolution, while the semi-official newspapers often referred to conspiracy in defining the events. Regarding the causes, the semi-official press saw the main causes of the protests in the foreign meddling and the influence of political groups, corruption was viewed as the root cause in the independent newspapers, and the social media pointed to the dictatorial rule of Mubarak as the cause. Approaches to ending the crisis differed significantly in the semi-official press, the independent press, and the social media. News stories in the semi-official newspapers concentrated on the regime supportive solutions that were in favour of Mubarak's regime or proposed transferring of power to the Vice President. Although independent newspapers abstained from providing solutions, the majority of the news articles called for an end to the control of communication and the Internet. The most common solution expressed in the social media posts was the resignation of Mubarak, followed by the calls for the elimination of state security, more independence to the media that would allow for the greater freedom of speech.

Another study on the news framing of the Egyptian revolution was conducted by Harlow and Johnson (2011). They analysed the news coverage of different media platforms in light of the protest paradigm, focusing on the New York Times and the materials uploaded on Global Voices and Twitter. The results showed that the New York Times' most frequent frame was oriented towards the drama, violence and deviance of protesters. Also, the New York Times was more likely than other media sources to employ de--legitimizing frames defined as marginalizing or discrediting the protesters' claims and actions and to rely on contextual frames that provided in -depth history and background about the protests. Although many articles referred to the protesters as striving for democracy and mentioned the longstanding autocratic rule of Mubarak, the New York Times coverage mainly portrayed protesters negatively, reducing their grievances and blaming them for the inconveniences caused, like travel delays and rising oil prices. The New York Times privileged official sources over the citizen sources and adhered more to the protest paradigm than the other media platforms. In contrast, Global Voices was more inclined to use the injustice frames that showed the moral outrage of the protesters and the significance of a problem. Global Voices was more sympathetic towards the protesters and tried to legitimize their actions and the causes behind them. For Twitter, the results showed that it was least likely of all three media sources to use a spectacle frame, an injustice frame, a sympathy frame, a legitimizing frame, or an accountability frame.

Golan (2013) studied the framing of the Egyptian 2011 uprising across the op-ed sections of the International Herald Tribune (IHT) and the European edition of the Wall Street Journal (WSJ). The results indicate that the two newspapers used many of the same key frames but presented them in a very different manner. For the $I H T$, the common frame was the speculations and concerns about future of democracy in the 
country followed by the causes of the revolution. The causes were mostly presented as a result of the dictatorship, oppression of citizens, and the lack of the basic freedoms. The next most popular frame was the role of the Muslim Brotherhood movement in the revolution and in the post-Mubarak Egypt: the IHT commentators seemed to undermine the threat posed by the Brotherhood but appeared to be concerned over the future of Israeli-Egyptian relations. Unlike the IHT, the WSJ raised grave concerns over the potential dangerous role of the Muslim Brotherhood in the future constellation of power. The second most salient frame in the WSJ op. -eds was the cause of the revolution that the majority of the commentators saw in the failed Mubarak's regime and the basic human rights it denied the citizens. The next key frame in the WSJ op-eds was the concerns over possible outcomes of the Egyptian revolution focusing on the threats Egypt might face after the revolution.

Another study about the Arab Spring was devoted to framing the Tunisian uprising by the protest activists and the representatives of the incumbent government. Building on the Snow et al.'s frame alignment, Lim (2013) argues that the protesters turned the self-immolation of Bouazizi into a revolutionary symbol of the fight for justice and dignity that united the citizens of Tunisia. Additionally, the amplification frame that presented Bouazizi as an unemployed university graduate who had to work as a street vendor was effective in mobilization by adding the salience to the public opinion and resonated with the youth problems and exemplified the process of frame bridging, which involves the linkage of a movement to those who share similar grievances but are disconnected or disengaged. This alignment frame successfully resonated with the sentiments of the entire society. At the same time, the incumbent Tunisian President Ben Ali tried to frame the protests as "riots" and called the protesters as "extremists" or "terrorists".

These studies used frame analysis on several protest activities. Building on their methodology and findings, the following section creates an analytical framework that can be applied to more than one case.

\section{The analytical framework}

The review of the literature on the framing of protest movements and uprisings indicates that there are two commonly used frames in the news: 1) the promotion of a particular problem definition and its evaluation and 2) the causal interpretation. Both dimensions build on the idea of diagnosis framing that identifies a problem and assigns blame (Benford \& Snow 2000). The primary importance of the problem lies in the capture of the issue under scrutiny and the most important actors, what constitutes the content of the debate (Matthes \& Kohring 2008). Therefore, descriptive characteristics of the protests events as such, their adherents and the opponents are central in framing protests and shaping message about them in one way or another. The manner in which events 
are portrayed constitutes a description bias that might differ from the objectives of the protesters and the interpretations of the observers (Smith et al. 2001). For instance, news media can frame protests by description given to the protesters, especially by attributing characteristics of their deviance and violence, attacking their appearances, by marginalizing the protesters, or downplaying the legitimacy and effectiveness of protests (Ashley \& Olson 1998; McLeod \& Detenber 1999; Schulenberg \& Chenier 2014). The negative portrayal of protests and the protesters is a result of the "protest paradigm" explained above, namely the news coverage is commonly supportive for the status quo of the powerful in the society (Shoemaker 1984; McLeod \& Detenber 1999; Boyle et al. 2005; Di Cicco 2010; Lee 2014).

The use of specific definitions of the popular mobilizations across countries, their adherents and opponents can be a powerful indicator of the assessment of the events. The assessment of the popular movements can be read in the use of the symbols that imply specific attitudes and positions towards an event. In practice, application of the metaphors, exemplars, catch phrases, depictions, visual images, and appeals can provide a certain discourse to the event and can carry a specific message to the reader (Lee et al. 2001, p.353). We identify whether the news stories are supportive of protests in general, protesters and the representatives of power by portraying them in favourable, neutral or unfavourable manner. This dimension of analysis refers both to the events per se and their actors. Given the diversity of national actors directly involved in the both revolutionary waves (including youth groups, civil society organizations, representatives of opposition parties, police, incumbents, military, and Islamist movements). There are three categories of actors: protesters / representatives of opposition / anti-incumbent forces are the driving forces of the uprisings, the incumbents / authorities consists of those targeted by the uprisings and the pro--incumbent forces / demonstrators.

According to Entman (1993, p.52), one of the frames' function is to diagnose causes - "identify the forces creating the problem". Referred to as a "responsibility frame" by Semetko and Valkenburg (2000), this dimension of analysis provides the presentation of an issue in such a way that attributes responsibility for its cause or solution to either a government, to individuals or groups and was predominant in the news. Causal beliefs on political affairs are important elements of public opinion that to a significant extent depends on the manner these issues are framed in the news. Attribution of causes shapes opinions, attitudes, judgments, and feelings and exert powerful impact on behaviour (Iyengar 1987, p.816). Previous research suggested that the attribution of the roots of an event is frequently presented in the news coverage, while the causal identification by the media was applied for Colour Revolutions and the Arab Spring (Khineyko 2005; Hamdy \& Gomaa 2012; Zhang \& Fahmy 2009; Hubenko 2012; Golan 2013), thus building an important element of media framing for 
both revolutionary waves.

The second dimension of our analytical framework differentiates between internal and external attributions of origins. Internal causality emphasizes the endogenous (domestic) factors that led to the mass protests, whereas external causality stresses the exogenous nature (foreign influence) of the events. Other causes refer to the impact of new means of communication and technological development that may trigger the spread of the protests from one country to another, i.e. contagion effect. This approach was inspired by Zhang and Fahmy (2009) who combined the framing with the attribution theory starting from the assumption that people tend to make internal causal attributions when positive things occur to them and external attributions when negative things happen. The following section presents the research design and explains how this analytical framework is applied.

\section{Research Design}

The links of Russia with the both waves make the Russian media perspective particularly important for this analysis. The Color Revolutions took place in post--Soviet countries that were under the Russian sphere of influence for decades, while the Arab region was considered the bastion of some authoritarian regimes with which Russia has good connections. The uprisings in Kyrgyzstan and Egypt were selected on the basis of their similarities: 1) they were not the first uprisings in their respective waves and their occurrence already indicates a diffusion process; 2) both were successful in reaching their objectives, namely the overthrow of incumbent presidents and the changes of power constellation; 3) they were not the most salient cases for Russia (like the Ukraine in the wave of the Color Revolutions or Syria during the Arab Spring) and 4) Russia did not engage actively in the events in any of the two countries, adopting a wait-and-see policy and refraining from supporting any side.

\section{Data and sampling strategy}

RIA Novosti, founded in 1941 as the Sovinformburo (Soviet Information Bureau), was one of the largest Russian news agencies. Since August 1991 RIA Novosti was within the competence of the Press and Information Ministry and a presidential decree in September 1993 made it the largest state-owned agency. In 2013, it was dissolved by presidential decree and absorbed by Rossiya Segodnya (Russia Today). This paper analyzes the online news of Ria Novosti instead of the printed one due to its growing popularity, easier access, and continuous decreasing readership of printed media in Russia (Voltmer 2000). Among the three largest online news agencies in Russia, ITAR $\cdots$ TASS, RIA Novosti and Interfax, RIA Novosti is the only one that provides a free access 
to the news archives.

For this study we use news reports related to the two events from the online archives of RIA Novosti. The selection took place in a two phase process. First, we collected all articles mentioning the events: for Kyrgyzstan 669 articles for the time period between 27 February (the first round or parliamentary elections) and 4 April 2005 (the resignation of Akaev) and 856 articles for Egypt between 25 January (when the uprising started) and 11 February 2011 (when Mubarak stepped down). Second, the articles were filtered according the relevance of their content for this analysis. Given the two analytical dimensions, the sample contains only articles related to the expression of popular protests or that have an explicit link to the events' causality. The articles are divided into three categories: news stories that describe the developments on the ground, opinion columns submitted by the RIA Novosti's journalists commenting the situation, and commentaries of experts (both Russian and international). ${ }^{1}$ The final sample for analysis includes 74 articles (53 news stories, 7 opinion articles and 14 expert interviews) for Kyrgyzstan and 110 articles (93 news stories, 7 opinion columns and 10 expert interviews) for Egypt (Figure 1).

News stories are mostly descriptions of protests and how they unfold, describe protesters' behaviour, what their requirements are, what kind of strategies they apply, who are the protesters and in what kind of mood they are (e.g. destruction and inconvenience). Also, articles contain information on the estimated number of protesters, the victims, and the geography of protests, organizational aspects of the opposition forces, attempts to negotiate between the opposition and the government, describe how the governmental forces, the police in particular, respond to the situation, whether they use force or not, the reaction of protesters on the actions of the government or concessions made, information about expected protests, describe and characterize the opposition (e.g. united or split). Opinion articles speculate about the trends, provide less factual information but more assessment judgments, and reflect the vision of an author that can be different from the opinion of editors. Expert interviews mostly contain reflections of prominent personalities, politicians and representatives of academia on what is happening, insinuations and concerns about the situation in the countries in general, the power balance, the future of the protests and their meanings for the country.

\section{Figure 1 about here}

\footnotetext{
${ }^{1}$ Experts include representatives of academia, political analysts, prominent figures and politicians. However, expert interviews do not include articles that report on the opinions expressed by high-level authorities including Ministries, presidential administration, the Prime Minister or the President.
} 
We were interested in articles reflecting the position of RIA Novosti regarding the events and thus we excluded a series of articles based on their content. More specifically, we did not include: secondary news that frequently mentioned the information about the uprisings on the background, but with focus on other topics (e.g. the situation with tourists, foreigners in the countries and their evacuation, safety of journalists and reporters etc.); positions and reactions of international organizations, of country leaders, foreign power representatives or authorities; positions of incumbents in Kyrgyzstan and Egypt regarding the situation in general or its origins; articles that report on the results of the parliamentary elections in Kyrgyzstan, as well as the work of the newly elected parliament; photo, video and audio materials; the weekly overviews of the main events that contained information on the events; articles related to the uprisings, but presenting an overview of the positions of the other media sources; brief breaking news messages that contain less than 50 words. Many articles were devoted to the victims of the protests and with them we proceeded as follows: when most of the text was about the victims of the protests (or on denial of information about victims) and the mass demonstrations were mentioned only as a background, the article was excluded. When articles included information about the victims but with a main focus on demonstrations, then they were included.

\section{Methodology and coding}

This study uses the deductive methodological approach of frame analysis as described by Matthes and Kohring (2008). This approach involves content analysing of predefined frames applied to the article as a coding unit; this procedure has been used in previous studies on framing protest events, uprisings or revolutions (Di Cicco 2010; Xu 2013). According to the first dimension of analysis, it is explored how RIA Novosti portrayed the events similarly using favourable, neutral or negative terms to depict them. We follow the procedure of Zhang and Fahmy (2009) and identify whether the events were depicted linguistically and symbolically in favourable, neutral or unfavourable terms. Favourable evaluation of the movements is reflected in framing them as "pro"democracy demonstration", "movement against regime/corruption/etc.", neutral terms are expressed in the use of the words such as "campaign", "event", "demonstration", "movement", or "rally", the negative assessment categories include an emphasis on the characteristics, such as "unrest", "conspiracy", "chaos", "riot", and "violence". We also looked at the depiction of actors during the uprisings since earlier research revealed that media tend to employ marginalization devices to emphasize protesters' violence, deviance, illegitimacy, internal dissention, and the weird appearances (Ashley \& Olson 1998; Xu 2013). We investigate whether RIA Novosti 
was more favourable towards protagonists or incumbents and their antagonists. Table 1 provides some examples of categories and coding used in this paper with respect to the first analytical dimension.

\section{Table 1 about here}

With respect to the second dimension, we identify internal causes (domestic grievances) such as the long... lasting dictatorship, widespread poverty and unemployment, corruption, oppression and repressiveness of regimes, injustice or lack of democracy and liberties. External attributions would stress the foreign influence, such as the exogenous origin of the uprisings and portray external actors as the conspirators. Given the geopolitical competition between Russia and the Western countries, the Russian media might use the frame of the "Western meddling", "foreign influence" or "geopolitical game" between the West and Russia. Moreover, the influence of the activist networks in promoting democracy, external contributions and the role of international actors in shaping the regional and national contexts are external causes of the events (Table 2).

\section{Table 2 about here}

One example is useful to illustrate how we did the coding for the two dimensions. The article on the uprising in Egypt entitled "Clashes of Demonstrators with Police Occurred again in the Centre of Cairo" [V Centre Kaira Vnov' Proizoshli Stolknovenija Demonstrantov s Policiej] from 26 January 2011 can be classified as a news story. It uses notions as "demonstrations", "events" or "clashes" when referring to the situation in general. The overall tone can be defined as neutral. Regarding the actors, protesters were defined as "demonstrators" throughout the article and this can also be classified as neutral. Referring to the authorities (in this case, police), the article attributes them neither favourable nor unfavourable characteristics; thus the second category of actors is absent. Pro-incumbent forces or demonstrators are not mentioned in the article at all and we coded the third category of actors as being also absent. Moving to the second dimension for analysis, the article refers to the demands of the protesters to improve the socio-economic situation in the country and to expand political freedoms, including the revocation of the state of emergency that was in force since 1981. Also, it mentions the revolution in Tunisia that took place sometime before the events in Egypt, what implicitly makes the reader associate these two events with each other. Therefore, the article as a whole can be categorized as identifying both internal and external causes for protests. 


\section{Results}

We divided the analysis in two phases that correspond to the developments of the protests. This approach allows to identify shifts in the perception of events and their actors. The two phases of the uprising in Kyrgyzstan are: 1) the first started with the first round of elections on 27 February 2005 and followed by the protests prevalently in the Southern provinces of the country and 2) the second started on 23 March 2005 when the opposition started its protests in the capital of the country that lasted until the collapse of the regime and the subsequent resignation of President Akaev on 4 April 2005. In Egypt the first phase Is between 25 January and 1 February 2011, marked by the eruption and intensification of protests, changes in the cabinet and appointment of a vice president. The second phase starts on 2 February, the beginning of the clash between Mubarak's supporters and protesters from Tahrir Square and lasts until resignation of Mubarak on 11 February 2011.

\section{Kyrgyzstan: The depiction of events}

The first phase of the Tulip Revolution (27 February - 22 March 2005) was covered by 27 articles, out of which 22 news stories, three opinion articles, and two expert interviews. In the news stories, the events as such in almost all cases are portrayed in a neutral manner (Table 3). In general, RIA Novosti's news neutrally describe the events and the news during this phase do not frame them as a revolution or an uprising but rather as a reaction to allegedly fraudulent elections. Protests are presented as confrontations between protesters and the government authorities for control over the administrative buildings and a struggle of the candidates defeated in the first round of the parliamentary election to contest and reverse the election results. The news stories report on seizure of the administrative buildings and road blocks, the installing parallel power, as well as appointing of popular "regional governors" and popular authorities. However, the coverage does not stress the destructions caused by these actions just mentioning the facts. For instance, on 20 March 2005 in the article entitled "In Kyrgyzstan, OMON (riot police) Freed Buildings seized by the Picketers" [V Kirgizii OMON Osvobodil Zahvachennye Piketchikami Zdanija], RIA Novosti frames these events in the following manner: "Protest campaigns started in Kyrgyzstan after the parliamentary elections. Those who disagree with their results seized buildings of several town halls".

The coverage of the first category of actors is mostly neutral in the news stories with only a few assessment characteristics. The most dominant definition of the first category of actors is the "protesters". In the beginning of the Kyrgyz uprising, the protesters are frequently associated with the official opposition, parties or 
defeated candidates. ${ }^{2}$ The second category of actors (incumbents and authorities) is less covered compared to the protesters, but whenever news stories refer to them they are neutral (only two are favourable and none negative). The dominating frame on authorities is an emphasis on their "wait-and--see attitude" towards the events. In 11 news stories, authorities are presented mostly as observers of the situation who do not resist the protesters and do not take any decisive actions against them. It is emphasized on a number of occasions that law enforcement agencies "were not taking any active actions against the protesters", refused from use of force, and guaranteed to abstain from use of force in the future. The third category - pro-governmental demonstrators - is the least covered and it is mostly presented in favourable terms as "peaceful local citizens" or as "calling for peace and stability".

All three opinion articles about the uprising in Kyrgyzstan can be classified as neutral with regard to the events as such, protesters, and the authorities. They all present the situation as the confrontation between the existing power and the opposition as a result of the parliamentary elections. Opinion articles draw similarities between events in Kyrgyzstan and the "velvet revolutions", as well as the preceding events in Georgia and Ukraine. For example, the article "Kyrgyzstan: Is There a Way out of the "Velvet" Crisis?" [Kirgizija: Est' li Vyhod iz "Barhatnogo" Krizisa?] claims that the situation is no longer a "velvet" revolution anymore since there are already casualties among the population and the law enforcement officers. The two expert interviews provided by Mikhail Margelov, a member of the Federation Council of Russia and the Chairman of its Foreign Affairs Committee and Lyubov Sliska, a member of the State Duma and deputy chairperson - apply negative framing of the event. For example, the interview from 21 March 2005 with Margelov takes a critical stance towards the events and defines the situation as an "attempt of an armed coup d'état". He refers to "a very dangerous tendency observed in the post--Soviet states to seize power by the force of arms. In a situation where such seizures under the guise of orange, chestnut or other "revolutions" occur, one cannot talk about adherence to any democratic principles". When referring to incumbents, he claims that they are "far from ideal democracy" and believes the fraud allegations during the parliamentary elections.

\section{Table 3 about here}

In the second phase of the Kyrgyz revolution, the articles (31 news stories, four opinion columns and 12 expert

\footnotetext{
${ }^{2}$ Only rarely protesters are defined as "organizers of illegal acts", "violators of public order", "uncontrolled crowd" or "destroyers of national heritage".
} 
interviews) focus on the confrontation and not on the issues behind them. Many news stories emphasize the effect the protests had on a life in the city and describe them as causing destructions and inconvenience to the citizens. Although the events are still called "protests" or "rallies", the commentators also refer to them as to "the revolution". Events are increasingly characterized as "riots" and "pogroms". The majority of the news stories report on the first category of actors in a neutral manner. The most commonly used definition of this group of actors is "opposition" (or "representatives of opposition", "opposition parties and movements", and "leaders of opposition"), followed by "demonstrators" and "protesters". 10 news stories report on the "crowd", pointing at the mass character of the events. A new narrative with regard to the first category of actors refers to the splits within the opposition induced by discontent: protesters distance themselves both from the leaders of the organized opposition and from street "hooligans" who took advantage of the situation. The actions of the second group of actors are mostly presented as neutral. While eight articles explain how authorities did not use force against the protestors and did not intervene in the events, arises also a reflection of the inability to maintain public order. The supporters of Akaev are also presented in a neutral manner: they are referred to as "demonstrators" or as "people in civilian clothes". Their actions are described as a confrontation with the opposition.

Three out of four opinion articles embed the events in Kyrgyzstan in the broader framework of revolutions in the region. They reflect the instability of the situation, chaos and possible dangerous implications (such as expansion of radical Islam, disintegration of the country, or destabilization of Fergana valley, what could pose a menace of intensification of trafficking of drugs) or spread of the same developments to the neighbouring countries and describe events in more negative terms than news stories covering the events during this phase. The most pessimistic picture is presented on 29 March 2005 in the article "Kyrgyzstan. Central Asian Domino Effect" [Kirgizija. Jeffekt sredneaziatskogo domino] that argues "Nevertheless, the 'small body' Kyrgyzstan - remains in a critical condition. It can, in the worst case scenario, disintegrate into the South and the North, disappear at all as a result of the absorption by neighbouring Uzbekistan and Kyrgyzstan, or become a victim of geopolitical claims of Islamist radicals". The portrayal of protesters is balanced and neutral in the most cases and authors take a neutral stance towards the incumbents although they frequently mention the political mistakes of Akaev. Pro-incumbent demonstrators are not mentioned in the opinion pieces at all. Expert interviews with prominent parliamentarians of the State Duma, committee chairs or deputy-chairs, political scientists, and leaders of NGOs and research institutes frame protests unfavourably. Words such as "riots", "disorder", and "destabilization" dominate in the rhetoric and experts criticized the violent strategy chosen by 
the protesters, their aggressiveness. The framing of incumbents varies: three experts portray them in a favourable way speaking about the elite legitimacy, while one expert negatively portrays them as ignoring the interests of certain groups in the population.

\section{Egypt: The depiction of events}

The majority of RIA Novosti news stories (29 out of 38) had a neutral approach during the first phase of the Egyptian uprising (Table 4). The neutral framing means that they presented a balanced picture of events without conveying judgments about regime features or protesters' behaviour. They stick to facts although they reported increasingly about clashes between protesters and police forces. They emphasized the "popular" and "mass" nature of the protests on a number of occasions, without calling the events a revolution. Nine news stories frame the events negatively and focus on the violence victims and chaos. Negative framing of the events in the news stories frequently define the events as "mass disorders" and "pogroms". An illustrative example is an article entitled "Millions" Opposition Demonstration Will Take Place in Egypt" ["Millionnaja" Demonstracija Oppozicii Projdet v Egipte] published on 1 February 2011: “The unrest was accompanied by looting and arsons, 150 people became the victims of the turmoil. (...) There are almost no policemen on the streets who ensure the safety of the population in a normal situation. This led to the unprecedented rampage of crime in the history of Egypt”.

The protesters are presented neutrally in 27 news stories and usually refer to their profile (young people or representatives of youth associations), affiliation to the Muslim Brotherhood or the absence of a single organizer of the protests. The 11 articles stories framed negatively towards them were published during the first four days of the uprising and blame protester for the initiation of events. The framing of incumbents / authorities is neutral in the first days of events: the law enforcement agencies are presented as trying to keep the public order (including the use of water cannons and tear gas) and mostly reacting to what protesters do. Also, there are eight articles in which these actors are presented in a favourable light especially when referring to concessions made by the incumbents after the first days. The incumbents are portrayed as cooperative and trying to find a solution for the situation in hand, e.g. the article from 1 February 2011 "Vice President of Egypt has Initiated a Dialogue with the Demonstrators in Tahrir Square [Vice-prezident Egipta Nachal Dialog s Demonstrantami na Ploshhadi Tahrir].

Opinion articles are neutral and express concern over the change of the status quo that can lead to the destabilization of the situation. Three out of four opinion articles associate the events in Egypt with the uprising 
in Tunisia and regard them as an attempt to replicate the success of the Tunisian Revolution. It can be read even in the title of one of the article, which is entitled "Tunisian Fire" in the Country of the Pharaohs" ["Tunisskij Ogon"' v Strane Faraonov], whereas the article entitled "Egypt and Strong "Shell” of Hosni Mubarak" [Egipet i Prochnaja "Skorlupa" Hosni Mubaraka] frames the events as "replication of "Tunisian exercise". The incumbent president and authorities are also depicted neutrally in the opinion articles. Two expert interviews have a neutral framing and refer to the events as "anti-.governmental campaigns", "revolutionary protests" or "classical revolutionary situation". Two other interviews (published on 1 February 2011) frame events and the protesters in favourable terms. For example, a former Prime Minister and the former head of the Ministry of Foreign Affairs Evgeny Primakov defines the events in Egypt as a classical social revolution of citizens fighting for a better quality of their lives and underscores the absence of religious context of the protests. He does not associate the protesters with the Islamists and points at the neutral role of the army. However, he expresses some concerns regarding the impact of these events on the future of the international relations.

\section{Table 4 about here}

During the second phase, the clashes remain the most dominant frame with regard to the events as such in the news stories published by RIA Novosti. However, the situation escalates and the tone of the articles becomes more critical toward the events. News stories depict the atmosphere of chaos and conflict, emphasize the severity and violent character of the clashes and condemn violence. Some news stories also stress the destructions and the inconvenience caused for ordinary citizens and underline the chaotic atmosphere, like in the news story entitled “Crowds of Opponents of Mubarak Attacking Horsemen in Cairo [Protivniki Mubaraka Tolpami Napadajut na Vsadnikov na Loshadjah v Kaire]" published on 2 February 2011: "Passer-by who do not participate in the campaigns hastily leave the streets and return home for fear of mass riots and pogroms, running shops are being closed". Getting closer to the end of the uprising, the news stories show more inclination towards the protesters and frame them in favourable terms with emphasis on the peacefulness of the movement, readiness to negotiate, and attempts to establish organizational structure. At the same time, pro-governmental demonstrations are framed negatively and their aggressiveness against protesters and journalists is laid out explicitly, e.g. in the article "Revolution via Twitter. Report from Cairo's Maidan" [Revoljucija Cherez Twitter. Reportazh s Kairskogo Majdana]. During the whole second phase, Mubarak and authorities in general are depicted as trying to find a compromise, making big concessions and promising reforms; but at the same time as unable to stop the 
protests and normalize the situation.

Two out of three opinion articles frame events, protesters and authorities in a neutral manner. None takes a critical stance towards Mubarak, nor commend his rule, accepting that assessment of such a personality needs a thorough analysis that should be done from different perspectives. An opinion article, "Barbarian with "Twitter" [Varvar s "tvitterom"] published on 2 February, takes a negative stance towards protesters and presents them as "barbarians", "uneducated" or "radicalized masses". Similarly, the event as such is framed negatively: "No matter how the 'Twitter revolution' in Egypt ends, it is unlikely that someone could envy political changes that urge the country to urgently evacuate all the tourists and cause collapse of the national economy". Almost all expert interviews frame the events, protesters and incumbents rather neutrally. Incumbent authorities are also portrayed neutrally as making concessions, while the army is presented as keeping neutrality.

\section{The Analysis of Causes}

All news stories published during the first phase of the Tulip Revolution present the internal factors as causes of the revolution (Table 5). In 17 articles, the election results are framed as the cause of the events and twice, the causes are presented as "turning personal problems into nationwide" implying the ambitions of the defeated candidates to express their disagreement with the election results. The causality of the events if presented in the opinion articles mostly as the result of the parliamentary elections and the confrontation between the incumbent authorities and the opposition forces that did not manage to secure an expected number of seats in the parliament. In one story, the situation is framed as a result not only of the elections, but also as a reaction to the corruption, injustice and poverty of the population. One expert interview considers the trigger of the events in the results of the elections. Though accepting the possible violations during the elections that triggered the uprising, the first expert interview entitled "Margelov: Events in Kyrgyzstan is an Armed Coup Attempt [Margelov: Sobytija v Kirgizii --- Popytka Vooruzhennogo Perevorota] argues that the current development of the crisis situation is similar to the "orange, chestnut and other revolutions" that are far from democratic principles and have other motivations.

News stories for the second phase of the uprising concentrate on the events and do not highlight the issues and reasons behind them. Only five out of 31 news stories provide causal implications of the issues. All five articles stress the internal causes and change from the requirement of power change in Kyrgyzstan to the association of protests with the presence of Akaev's supporters in the parliament. Opinion articles refer extensively to internal causes of the events such as flawed elections, corruption, nepotism, control over the 
economics, poverty and neglect of the Southern clans and other socio-economic grievances. The external factors that triggered the revolution are identified in the form of European and American funds, anti-Russia forces and a general influence of other countries in the region, e.g. the article "Kyrgyzstan. Central Asian Domino Effect" [Kirgizija. Jeffekt sredneaziatskogo domino] from 29 March 2005. Eight out of 11 causal implications from expert interviews during the second phase of the Kyrgyz revolution, focus on internal causes such as clan system and underrepresentation of Southerners in the power structures of the country, discontent with corruption and poverty, and flawed parliamentary elections. The three articles touching upon external causes link the uprising in Kyrgyzstan with the previous events in Georgia and Ukraine and identify a "Western scenario" against Russia.

\section{Table 5 about here}

The internal causes of events dominate the news stories during the first phase of the Egyptian uprising. Protests are portrayed as driven by a broad range of economic problems, the lack of political freedoms, widespread corruption, unemployment, high prices, discontent with the long Mubarak's rule, police atrocities, and violations during the parliamentary elections, demands to abrogate the emergency law and to initiate changes in the electoral law. After the first days of the uprising, the list of internal causes expands to the demands to release detained protesters. Furthermore, the death of demonstrators is portrayed as a trigger of the further protests. External causes are mentioned in seven news stories and mainly hint at links with the Tunisian event; external causes are present in the news stories only before the resignation of the government. Internal causes are mentioned in three opinion articles and they are similar to the categories covered in the news stories, namely tiredness of the Mubarak's rule, poverty and the lack of the freedoms, and social problems. At the same time, two opinion articles emphasize that the events in Egypt were provoked by the Tunisian revolution. In the expert interviews internal causes also prevail: poverty, corruption, high unemployment rates or rising prices. External causes are mentioned in only two expert interviews and they consist of linkages with similar events.

The news stories covering the second phase of the Egyptian uprising shift the focus from the problems in Egypt and frame the events as caused by protesters' demand for an immediate resignation of Mubarak. Socio. -political problems as internal causes are replaced by protesters' aim to change the regime. Clashes are framed as initiated by the presidential speech, whose guarantees of reforms appeared insufficient for the protesters. Opinion articles focus on other causes than the internal ones, namely the Internet and new technologies. Expert interviews focus on internal causes like the requirements of reforms and resignation of the incumbent president. The only 
external cause refers to Sudan's referendum on self--determination that could be a trigger for the events in Egypt.

\section{Discussion and Conclusion}

This paper compared the framing of the uprisings in Kyrgyzstan and Egypt in the coverage of RIA Novosti. It analysed 184 different articles (74 for Kyrgyzstan and 110 for Egypt) to identify and compare how events were described and assessed. The results indicate a relatively neutral approach with quite a few nuances in which the news agency depicted protesters or authorities in favourable light depending on the moment of the event. These nuances are best highlighted in the framing similarities and differences between the two events. To begin with the similarities, the most frequently used frame in both cases is the conflict frame that describes the events as the confrontation of the protesters with the authorities. RIA Novosti does not define them as revolutions from the beginning (with the exception of expert interviews covering the first phase of Egyptian uprising). In general, RIA Novosti's news stories are mostly neutral in framing the events and maintain a balanced approach toward both uprisings. However, in both countries, the framing of the second phase of the uprising in the news stories was more negative and pessimistic with more news accounts emphasizing chaos and disorder.

Another similarity is that protesters are presented neutrally but the emphasis changes throughout the uprisings. The popular movement is not presented as a conspiracy but instead as attempts to make voices of opposition (anti-regime) heard. The split and lack of unity among the protesters appears as a prominent frame in the second phases of the uprisings. They are rarely framed in a favourable manner or as a movement for more democracy. The negative portrayal of the demonstrations is emphasized by drawing a link between the continuation of the protests and the prevalence of chaotic atmosphere, which is stressed in the news stories on both uprisings. RIA Novosti has an inclination to present authorities (in particular law enforcing) in a more favourable light compared to protesters since the former are associated with stability and status quo. The news agency supported the measures and steps taken by the authorities that are depicted as keeping the order, guaranteeing stability, and trying to find solutions. Police forces are portrayed as patient, ready to compromises and not using force. Nevertheless, the agency did not frame incumbents positively and pointed at their authoritarian rule and existing socio-political problems. In brief, RIA Novosti appears to support the status quo in general not the regimes. Although one would expect Ria Novosti to dedicate attention to the exogenous nature of revolutions - the existing waves, domino effect, Western involvement, and networks between activist- the vast majority of articles is dedicated to internal determinants, i.e. socio-political problems and domestic grievances. External causality appears mainly in the opinion pieces and expert interviews. 
With respect to differences, RIA Novosti is more critical toward the Egyptian events than tin Kyrgyzstan. Articles focus more on clashes, destruction and destabilization of the situation as a whole. The fear of an Islamist takeover is emphasized on a number of occasions. In the beginning of the second phase, antagonism towards the uprising and protesters grows. The framing of Ria Novosti gets slightly more neutral towards the end of the event when violence is at lower levels. In that sense, there is a significant shift in Ria Novosti's presentation of the Egyptian opposition in the second phase of the uprising. In contrast, in Kyrgyzstan the coverage was more balanced and the neutral line was maintained throughout the phases of protests. The difference in the dynamics of coverage can be explained by the way events unfolded in both cases. The opinion articles from the beginning of the events put the uprising in Kyrgyzstan into a broader context and associate them with a trend of revolutions on the post-Soviet space. In contrast with the coverage of the events in Kyrgyzstan, links with other revolutions and wave dynamics are more emphasized in the beginning of the Egyptian uprising that took place right after Tunisian revolution.

The implications of this study move beyond the comparison of the two cases. At theoretical level, the study proposes an analytical framework that is not context sensitive and can be applied to other events. The innovation of our approach lies in the systematic approach of two separate protest phases, divided according to their internal logic, and of three types of media articles. The major advantage was that we could identify the shift in coverage and changes in framing, all explained in detail in the paper. Furthermore, the findings confirm the conclusions of earlier studies that showed how the framing protest events is in line with the protest paradigm. At empirical level, this paper fills an important void in the literature by comparing two cases from different revolutionary waves. In spite of the temporal difference of six years and geographic position, our analysis reveals that the coverage of these two events shares significant similarities. Ria Novosti used a similar framing with respect to the events as such, their actors and the causality. Although it followed the path of neutrality in general, the news agency tried to influence readers by assessing the conflicts. There were instances of the media bias against the popular movement, some preference towards the authorities, and an inclination towards the maintenance of the status quo.

This study opens the floor to several avenues for further research. Due to its exploratory goal, this paper could not explain why RIA Novosti framed these events the way it did. Further research can conduct qualitative interviews with the authors or editorial staff to understand the framing process. Also, our analysis was limited to one news agency and findings cannot be generalized to other media outlets. Future studies can strive for a comparative perspective by including either more news agencies worldwide or increasing the diversity of media 
types (especially social media coverage for more recent events). The application of the two framing dimensions to more types of media and more protests and uprisings may lead to the identification of patterns that can help us better understand the role of media in contemporary events. 


\section{List of references:}

Ashley, L. \& Olson, B., 1998. Constructing Reality: Print Media’s Framing of the Women's Movement, 1966 to 1986. Journalism \& Mass Communication Quarterly, 75(2), pp.263-277.

Benford, R.D. \& Snow, D.A., 2000. Framing Processes and Social Movements: An Overview and Assessment. Annual Review of Sociology, 26(1), pp.611-639.

Boyle, M.P. et al., 2005. Newspapers and Protest: An Examination of Protest Coverage from 1960 to 1999. Journalism \& Mass Communication Quarterly, 82(3), pp.638-653.

Bunce, V. \& Wolchik, S., 2006a. Favorable Conditions and Electoral Revolutions. Journal of Democracy, 17(4), pp.5-18.

Bunce, V. \& Wolchik, S., 2006b. International Diffusion and Postcommunist Electoral Revolutions. Communist and Post-Communist Studies, 39(3), pp.283-304.

Di Cicco, D.T., 2010. The Public Nuisance Paradigm: Changes in Mass Media Coverage of Political Protest Since the 1960s. Journalism \& Mass Communication Quarterly, 87(1), pp.135-153.

Diamond, L., 2011. A Fourth Wave or False Start? Democracy After the Arab Spring. Foreign Affairs, (21 May).

Entman, R.M., 1993. Framing: Toward Clarification of a Fractured Paradigm. Journal of Communication, 43(4), pp.51-58.

Gamson, W.A. \& Modigliani, A., 1987. The Changing Culture of Affirmative Action. In R. G. Braungart \& M. M. Braungart, eds. Research in Political Sociology. Greenwich: JAI Press Incorporated, pp.137-177.

Gitlin, T., 1977. Spotlights and Shadows: Television and the Culture of Politics. Mass Culture, Political Consciousness and English Studies, 38(8), pp.789-801.

Gitlin, T., 1980. The Whole World Is Watching, Berkeley: University of California Press.

Goffman, E., 1974. Frame Analysis. An Essay on the Organization of Experience, New York: Harper \& Row.

Golan, G.J., 2013. The gates of op-ed diplomacy: Newspaper framing the 2011 Egyptian revolution. International Communication Gazette, 75(4), pp.359-373.

Gottlieb, J., 2015. Protest News Framing Cycle: How The New York Times Covered Occupy Wall Street. International Journal of Communication, 9, pp.231-253.

Hamdy, N. \& Gomaa, E.H., 2012. Framing the Egyptian Uprising in Arabic Language Newspapers and Social Media. Journal of Communication, 62(2), pp.195-211.

Harlow, S. \& Johnson, T.J., 2011. Overthrowing the Protest Paradigm? How The New York Times, Global 
Voices and Twitter Covered the Egyptian Revolution. International Journal of Communication, 5, p.1359-1374 .

Hess, S., 2016. Sources of Authoritarian Resilience in Regional Protest Waves: The Post-Communist Colour Revolutions and 2011 Arab Uprisings. Government and Opposition, 51(01), pp.1-29.

Hubenko, D., 2012. Frame Analysis of The New York Times and Izvestia Coverage of the 2004 Presidential Elections and the Orange Revolution in Ukraine. Maristerium. Political studio, 10, pp.16-24.

Iyengar, S., 1987. Television News and Citizens' Explanations of National Affairs. American Political Science Review, 81(3), pp.815-832.

Khineyko, I., 2005. The View from Russia: Russian Press Coverage of the 2004 Presidential Elections in Ukraine. Canadian Slavonic Papers, 47(3/4), pp.265-291.

Koesel, K.J. \& Bunce, V., 2013. Diffusion---Proofing: Russian and Chinese Responses to Waves of Popular Mobilizations against Authoritarian Rulers. Perspectives on Politics, 11(3), p.753--768.

Lee, C.-C. et al., 2001. Through the eyes of U.S. media: banging the democracy drum in Hong Kong. Journal of Communication, 51(2), pp.345-365.

Lee, F.L.F., 2014. Triggering the Protest Paradigm: Examining Factors Affecting News Coverage of Protests. International Journal of Communication, 8, p.2725--2746.

Lim, M., 2013. Framing Bouazizi: "White lies", hybrid network, and collective/connective action in the 2010-11 Tunisian uprising. Journalism, 14(7), pp.921-941.

Lundgren--Jörum, E., 2012. Discourses of a Revolution: Framing the Syrian uprising. Ortadogu Etütleri, 3(2), pp.9-39.

Lynch, M., 2014. The Arab Uprisings Explained. New Contentious Politics in the Middle East, New York: Columbia University Press.

Matthes, J. \& Kohring, M., 2008. The Content Analysis Of Media Frames: Toward Improving Reliability And Validity. Journal of Communication, 58(2), pp.258-279.

McLeod, D.M. \& Detenber, B.H., 1999. Framing effects of television news coverage of social protest. Journal of Communication, 49(3), pp.3-23.

Nelson, T.E., Clawson, R.A. \& Oxley, Z.M., 1997. Media Framing of a Civil Liberties Conflict and Its Effect on Tolerance. American Political Science Review, 91(3), pp.567-583.

Noakes, J.A. \& Johnston, H., 2005. Frames of Protest: A Road Map to a Perspective. In H. Johnston \& J. A. Noakes, eds. Frames of Protest: Social Movements and the Framing Perspective. Lanham: Rowman \& 
Littlefield, pp. 1-32.

Peng, Z., 2008. Framing the Anti-War Protests in the Global Village: A Comparative Study of Newspaper Coverage in Three Countries. International Communication Gazette, 70(5), pp.361-377.

Reese, S.D., 2001. Framing public life: A bridging model for media research. In S. D. Reese, O. H. Gandy, \& A.

E. Grant, eds. Framing Public Life: Perspectives on Media and our Understanding of the Social World. Mahwah: Lawrence Erlbaum, pp. 7-31.

Scheufele, D.A., 1999. Framing as a theory of media effects. Journal of Communication, 49(1), pp.103-122.

Schulenberg, J.L. \& Chenier, A., 2014. International Protest Events and the Hierarchy of Credibility: Media Frames Defining the Police and Protestors as Social Problems. Canadian Journal of Criminology and Criminal Justice, 56(3), pp.261-294.

Semetko, H.A. \& Valkenburg, P.M., 2000. Framing European Politics: A Content Analysis of Press and Television News. Journal of Communication, 50(2), pp.93-109.

Shoemaker, P.J., 1984. Media Treatment of Deviant Political Groups. Journalism \& Mass Communication Quarterly, 61(1), pp.66-82.

Smith, J. et al., 2001. From Protest to Agenda Building: Description Bias in Media Coverage of Protest Events in Washington, D.C. Social Forces, 79(4), pp.1397-1423.

Xu, K., 2013. Framing Occupy Wall Street: A Content Analysis of the New York Times and USA Today. International Journal of Communication, 7, pp.2412-2432.

Zhang, J. \& Fahmy, S., 2009. Colored Revolutions in Colored Lenses: A Comparative Analysis of U.S. and Russian Press Coverage of Political Movements in Ukraine, Belarus, and Uzbekistan. International Journal of Communication, 3, pp.517-539. 
Table 1: Categories and coding for the first analytical dimension

\begin{tabular}{|c|c|c|c|}
\hline & Favourable & Neutral & Unfavourable \\
\hline Event & $\begin{array}{l}\text { Pro--democracy movement } \\
\text { Movement against a } \\
\text { repressive regime } \\
\text { Movement against corruption }\end{array}$ & $\begin{array}{l}\text { Campaign } \\
\text { Rally } \\
\text { Event } \\
\text { Demonstration } \\
\text { Movement } \\
\text { Uprising } \\
\text { Protests } \\
\text { Revolution } \\
\text { Conflict } \\
\text { Clashes }\end{array}$ & $\begin{array}{c}\text { Turmoil } \\
\text { Upheaval } \\
\text { Revolt } \\
\text { Riot } \\
\text { Unrest } \\
\text { Violence } \\
\text { Chaos } \\
\text { Conspiracy } \\
\text { Causing inconvenience or } \\
\text { annoyance }\end{array}$ \\
\hline $\begin{array}{c}\text { Protesters / } \\
\text { Representatives of } \\
\text { opposition / Anti-.. } \\
\text { incumbent forces }\end{array}$ & $\begin{array}{l}\text { Fighting for democracy, } \\
\text { freedom, stability, order }\end{array}$ & $\begin{array}{c}\text { Protesters } \\
\text { Demonstrators }\end{array}$ & $\begin{array}{c}\text { Hooligans } \\
\text { Deviants } \\
\text { Disruptive } \\
\text { Corrupt } \\
\text { Irrational } \\
\text { Violent } \\
\text { Weird appearances and } \\
\text { way to dress }\end{array}$ \\
\hline $\begin{array}{c}\text { Incumbents / state } \\
\text { authorities }\end{array}$ & $\begin{array}{l}\text { Supporters of the order } \\
\text { and stability }\end{array}$ & $\begin{array}{c}\text { Neutral portrayal of } \\
\text { their actions described } \\
\text { without application of } \\
\text { Assessment } \\
\text { Characteristics }\end{array}$ & $\begin{array}{l}\text { Deviants } \\
\text { Disruptive } \\
\text { Corrupt } \\
\text { Irrational } \\
\text { Violent }\end{array}$ \\
\hline $\begin{array}{c}\text { Pro-"incumbent } \\
\text { forces / demonstrators }\end{array}$ & $\begin{array}{l}\text { Supporters of the order } \\
\text { and stability }\end{array}$ & $\begin{array}{l}\text { Pro-incumbent forces } \\
\text { Pro-incumbent } \\
\text { Demonstrators } \\
\text { Supporters of the } \\
\text { incumbent president }\end{array}$ & $\begin{array}{c}\text { Hooligans } \\
\text { Deviants } \\
\text { Disruptive } \\
\text { Corrupt } \\
\text { Irrational } \\
\text { Violent } \\
\text { Weird appearances and } \\
\text { way to dress }\end{array}$ \\
\hline
\end{tabular}

Table 2: Categories and coding for the second analytical dimension

\begin{tabular}{cccc} 
& External causes & Internal causes & Other causes \\
\cline { 2 - 4 } & Foreign influence, pressure & Regime oppression & \\
sponsorship, diplomatic & Long--lasting dictatorship & \\
support & Absence of liberties & \\
Foreign strategy to promote & Problems of democracy & Impact of media \\
democracy abroad & Corruption & \\
Western meddling & Poverty & \\
Geopolitical game & Unemployment & Injustice & \\
Diffusion of the & Election fraud &
\end{tabular}

Table 3: The description of events in the Kyrgyz uprising

\begin{tabular}{|c|c|c|c|c|c|}
\hline First phase & Favourable & Neutral & Unfavourable & N/A & Total \\
\hline \multicolumn{6}{|l|}{ News stories } \\
\hline Event & 0 & 22 & 0 & 0 & \multirow{3}{*}{22} \\
\hline Protesters / Opposition/ Anti-incumbent forces & 0 & 22 & 0 & 0 & \\
\hline Incumbents/authorities & 2 & 14 & 0 & 6 & \\
\hline
\end{tabular}


Pro-incumbent forces/demonstrators

2

Opinion articles

Event

Protesters / Opposition/ Anti-incumbent forces

Incumbents/authorities

Pro-incumbent forces/demonstrators

Expert interviews

Event

Protesters / Opposition/ Anti--incumbent forces

Incumbents/authorities

Pro-incumbent forces/demonstrators

\section{Second Phase}

\section{News stories}

Event

Protesters / Opposition/ Anti--incumbent forces

Incumbents/authorities

Pro--incumbent forces/demonstrators

\section{Opinion articles}

Event

Protesters / Opposition/ Anti--incumbent forces

Incumbents/authorities

Pro-incumbent forces/demonstrators

\section{Expert interviews}

Event

Protesters / Opposition/ Anti-incumbent forces

Incumbents/authorities

Pro-incumbent forces/demonstrators

$0 \quad 3$

1

0

19

$\begin{array}{lllll}0 & 3 & 0 & 0 & 3 \\ 0 & 3 & 0 & 0 & \\ 0 & 0 & 0 & 3\end{array}$

3

.

\begin{tabular}{|c|c|c|c|c|c|}
\hline Event & 0 & 0 & 2 & 0 & \multirow{4}{*}{2} \\
\hline Protesters / Opposition/ Anti-incumbent forces & 0 & 1 & 1 & 0 & \\
\hline Incumbents/authorities & 0 & 0 & 1 & 1 & \\
\hline Pro-incumbent forces/demonstrators & 0 & 0 & 0 & 2 & \\
\hline \multicolumn{6}{|l|}{ Second Phase } \\
\hline \multicolumn{6}{|l|}{ News stories } \\
\hline Event & 0 & 28 & 3 & 0 & \multirow{4}{*}{31} \\
\hline Protesters / Opposition/ Anti-incumbent forces & 1 & 14 & 4 & 2 & \\
\hline Incumbents/authorities & 0 & 20 & 2 & 9 & \\
\hline Pro-incumbent forces/demonstrators & 0 & 8 & 0 & 0 & \\
\hline \multicolumn{6}{|l|}{ Opinion articles } \\
\hline Event & 0 & 2 & 2 & 0 & \multirow{4}{*}{4} \\
\hline Protesters / Opposition/ Anti-incumbent forces & 0 & 3 & 1 & 0 & \\
\hline Incumbents/authorities & 0 & 4 & 0 & 0 & \\
\hline Pro-incumbent forces/demonstrators & 0 & 0 & 0 & 4 & \\
\hline \multicolumn{6}{|l|}{ Expert interviews } \\
\hline Event & 0 & 4 & 8 & 0 & \multirow{4}{*}{12} \\
\hline Protesters / Opposition/ Anti-incumbent forces & 0 & 4 & 3 & 5 & \\
\hline Incumbents/authorities & 3 & 2 & 1 & 6 & \\
\hline Pro-incumbent forces/demonstrators & 0 & 0 & 0 & 12 & \\
\hline
\end{tabular}


Table 4: The description of events in the Egypt uprising

\begin{tabular}{|c|c|c|c|c|c|}
\hline First phase & Favourable & Neutral & Unfavourable & N/A & Total \\
\hline News stories & & & & & \multirow{5}{*}{38} \\
\hline Event & 0 & 29 & 9 & 0 & \\
\hline Protesters / Opposition/ Anti-incumbent forces & 0 & 27 & 11 & 0 & \\
\hline Incumbents/ authorities & 8 & 27 & 1 & 2 & \\
\hline Pro-incumbent forces/demonstrators & 0 & 4 & 0 & 34 & \\
\hline \multicolumn{6}{|l|}{ Opinion articles } \\
\hline Event & 0 & 4 & 0 & 0 & \multirow{4}{*}{4} \\
\hline Protesters / Opposition/ Anti-incumbent forces & 0 & 4 & 0 & 0 & \\
\hline Incumbents/ authorities & 0 & 4 & 0 & 0 & \\
\hline Pro-incumbent forces/demonstrators & 0 & 0 & 0 & 4 & \\
\hline \multicolumn{6}{|l|}{ Expert interviews } \\
\hline Event & 2 & 2 & 1 & 0 & \multirow{4}{*}{5} \\
\hline Protesters / Opposition/ Anti-incumbent forces & 2 & 2 & 1 & 0 & \\
\hline Incumbents/ authorities & 1 & 1 & 1 & 2 & \\
\hline Pro-incumbent forces/demonstrators & 0 & 0 & 0 & 5 & \\
\hline \multicolumn{6}{|l|}{ Second phase } \\
\hline \multicolumn{6}{|l|}{ News stories } \\
\hline Event & 1 & 39 & 15 & 0 & \multirow{4}{*}{55} \\
\hline Protesters / Opposition/ Anti--incumbent forces & 4 & 38 & 12 & 1 & \\
\hline Incumbents/ authorities & 5 & 39 & 1 & 10 & \\
\hline Pro--incumbent forces/demonstrators & 1 & 19 & 15 & 20 & \\
\hline \multicolumn{6}{|l|}{ Opinion articles } \\
\hline Event & 0 & 2 & 1 & 0 & \multirow{4}{*}{3} \\
\hline Protesters / Opposition/ Anti--incumbent forces & 0 & 2 & 1 & 0 & \\
\hline Incumbents/ authorities & 0 & 3 & 0 & 0 & \\
\hline Pro--incumbent forces/demonstrators & 0 & 0 & 0 & 3 & \\
\hline \multicolumn{6}{|l|}{ Expert interviews } \\
\hline Event & 0 & 5 & 0 & 0 & \multirow{4}{*}{5} \\
\hline Protesters / Opposition/ Anti-.incumbent forces & 1 & 4 & 0 & 0 & \\
\hline Incumbents/ authorities & 0 & 4 & 0 & 1 & \\
\hline Pro--incumbent forces/demonstrators & 0 & 1 & 1 & 3 & \\
\hline
\end{tabular}


Table 5: The analysis of causes in news about the Kyrgyz and Egyptian uprisings

\begin{tabular}{llcccc}
\hline \multirow{2}{*}{ Kyrgyzstan } & & External & Internal & Other & Total \\
\cline { 3 - 6 } First phase & News stories & 0 & 26 & 0 & 26 \\
& Opinion articles & 0 & 4 & 4 & 4 \\
& Expert interviews & 1 & 2 & 0 & 3 \\
\hline \multirow{3}{*}{ Second phase } & News stories & 0 & 5 & 0 & 5 \\
& Opinion articles & 4 & 8 & 0 & 12 \\
& Expert interviews & 3 & 8 & 0 & 11 \\
Egypt & & & & & \\
First phase & News stories & 16 & 74 & 0 & 90 \\
& Opinion articles & 2 & 3 & 1 & 6 \\
\hline \multirow{2}{*}{ Second phase } & Expert interviews & 3 & 7 & 1 & 11 \\
& News stories & 0 & 50 & 1 & 51 \\
& Opinion articles & 0 & 1 & 2 & 3 \\
\hline
\end{tabular}

